\title{
Sistem Pendukung Keputusan Untuk Pemilihan Siswa Berprestasi Dengan Metode Analytical Hierarchy Process (AHP) Dan Technique For Order Of Preference By Similarity To Ideal Solution (TOPSIS)
}

\author{
Akhmad Luthfi Rahman ${ }^{1)}$, Muhammad Hasbi ${ }^{2)}$, Setiyowati ${ }^{3)}$ \\ 1) Program Studi Sistem Informasi, STMIK Sinar Nusantara Surakarta \\ 2) Program Studi Teknik Informatika, STMIK Sinar Nusantara Surakarta \\ 3) Program Studi Manajemen Informatika, STMIK Sinar Nusantara Surakarta \\ 1) luthfi@gmail.com; ${ }^{2)}$ mhasbi@ sinus.ac.id; ${ }^{3)}$ setiyowati@ sinus.ac.id
}

\begin{abstract}
Public High Schools of Surakarta are in an effort to improve student achievement by giving rewards to students who have the best performance. The selection process for SMA N 7 (Public High School of 7 Surakarta) still uses a manual process so it is not objective and it takes a long time. Therefore, we need an application that can support the process of selecting high achieving students in SMA $N 7$ Surakarta. This application later can help to make decisions about the selection of high achieving students by changing the value of standard criteria into numbers. Then, the right method for this research is the AHP (Analytical Hierarchy Process) while the TOPSIS (Technique for Order of Preference by Similarity to Ideal Solution) is for its rankings. Because this method is able to produce effective, objective and efficient decisions. The system development in this research uses the waterfall model. The system design uses object oriented approach, Use Case Diagram, Activitv, Squence Diagram, Class Diagram. The programming languages use PHP and MySQL. Meanwhile, Supporting software used Notepad ++ and XAMPP as a virtual server and the testing programs use BlackBox Testing. The results of this study are Student Achievement Decision Application with the calculation of Analytical Hierarchy Process and Technique For Order Of Preference By Similarity To Ideal Solution methods.
\end{abstract}

Keywords : Waterfall, Analytical hierarchy process, Technique for Order of Preference by Similarity to Ideal Solution, BlackBox

\section{PENDAHULUAN}

SMA Negeri 7 Surakarta adalah salah satu sekolah menengah terbaik di Surakarta, Untuk meningkatkan prestasi siswanya, SMA N 7 Surakarata memberikan reward bagi siswa yang memiliki prestasi terbaik. Seleksi SMA N 7 masih menggunakan proses manual sehingga ditemukan beberapa permasalahan, seperti adanya penilaian yang tidak objektif, serta proses penilaian membutuhkan waktu lama. Maka dibutuhkan suatu aplikasi yang dapat mendukung proses pemilihan siswa berprestasi yang dapat mengubah nilai kriteria standar menjadi angka. Dibutuhkan suatu metode yang dapat mengubah nilai kriteria standar tersebut menjadi angka yaitu Metode AHP (Analytical Hierarchy Process) karena nilai kriteria dari sekolah berupa suatu keterangan. Contohnya nilai sikap baik dan buruk, sedangkan untuk melakukan perangkingan siswa dengan metode TOPSIS (Technique for Order of Preference by Similarity to Ideal Solution). Metode ini mampu menghasilkan keptusan efektif, objektif dan efisien. Maka akan dibuat sebuah Sistem

Pendukung Keputusan pemilihan siswa berprestasi dan penerapan metode AHP (Analytical Hierarchy Process) dan TOPSIS (Technique for Order of Preference by Similarity to Ideal Solution).

\section{TINJAUAN PUSTAKA}

\subsection{Penelitian Terkait}

Penelitian terkait Kombinasi metode AHP dan TOPSIS adalah pada (1) Penerapan pemilihan bahan pewarna alami batik tulis bagi pengrajin batik tulis, pemilihan bahan 
pewarna alami yang tepat berpengaruh terhadap warna, corak,dan kecerahan kain batik tulis. Metode AHP digunakan untuk menentukan bobot masing-masing kriteria. Metode TOPSIS digunakan untuk menentukan prioritas alternatif (Chamid \& Murti, 2018). (2) Metode AHP dan TOPSIS juga diterapkan untuk Menentukan Alat Tangkap yang sesuai bagi Nelayan di Madura (Heru Lumaksono, 2017). (3) Metode AHP dan TOPSIS juga diterapkan untuk seleksi penerimaan siswa program percepatan belajar (akselerasi) di SMP Negeri di Wonogiri, (Sejati Purnomo, Widya Sihwi, \& Anggrainingsih, 2013).

Kombinasi metode AHP dan TOPSIS dipilih karena memliki kelebihan berdasar pada matriks perbandingan pasangan dan melakukan analisis konsistensi. Sedangkan metode TOPSIS dapat menyelesaikan pengambilan keputusan secara praktis, karena konsepnya sederhana dan mudah dipahami, komputasinya efisien, serta memiliki kemampuan mengukur kinerja relatif dari alternatif-alternatif keputusan (Juliyanti, Mohammad Isa Irawan, 2011) (Purwitasari \& Pribadi, 2015).

\subsection{Sistem Pendukung Keputusan (SPK)}

Sistem pendukung keputusan pertama kali diperkenalkan oleh G. Anthony Gorry dan Michael S. Scott Marton, mereka mengembangkan kerangka pemikiran tentang pemanfaatan aplikasi komputer pada proses pengambilan keputusan bagi level manajemen. (Kusumadewi, 2005)

\subsection{Analytical Hierarchy Process (AHP)}

Analytical Hierarchy Process (AHP) merupakan metode yang digunakan untuk membantu menentukan keputusan yang dikembangkan oleh Thomas L. Saaty pada tahun 1970-an. Metode AHP dapat digunakan untuk mengukur tingkat kepentingan hal-hal yang bersifat kualitatif dengan tingkat kompleksitas yang tinggi (Saaty, 2008). Metode AHP dapat dilakukan dengan langkah-langkah sebagai berikut :

1. Membuat matriks berpasangan

$$
A=\left[a_{i m}\right]=\left[\begin{array}{cccc}
1 & a_{12} & \ldots & a_{1 n} \\
\frac{1}{a_{12}} & 1 & \ldots & a_{2 n} \\
\ldots & \ldots & \ldots & \ldots \\
\frac{1}{a_{1 n}} & \frac{1}{a_{2 n}} & \ldots & 1
\end{array}\right]
$$

$\mathrm{i}, \mathrm{m}=1,2, \ldots, \mathrm{n}=$ indeks kriteria-kriteria siswa berprestasi.

Menurut Saaty penilaian perbandingan terbaik dalam mengekspresikan pendapat digunakan skala 1 sampai dengan 9, seperti pada Tabel 1. (Saaty, 2008)

Tabel 1. Tabel penilaian kepentingan relatif kriteria menggunakan skala Saaty

\begin{tabular}{|c|c|c|}
\hline Kep & Keterangan & Penjelasan \\
\hline 1 & $\begin{array}{l}\text { kedua elemen sama } \\
\text { pentingnya }\end{array}$ & $\begin{array}{l}\text { Dua elemen mempunyai pengaruh yang sama besar terhadap } \\
\text { tujuan }\end{array}$ \\
\hline 3 & $\begin{array}{l}\text { Elemen yang satu sedikit } \\
\text { lebih penting dari pada } \\
\text { elemen yang lain }\end{array}$ & $\begin{array}{l}\text { Pengalaman dan penilaian sedikit menyokong satu elemen } \\
\text { dibanding elemen lainnya }\end{array}$ \\
\hline 5 & $\begin{array}{l}\text { Elemen yang satu lebih } \\
\text { penting dari pada elemen } \\
\text { lainya }\end{array}$ & $\begin{array}{l}\text { Pengalaman dan penilaian sangat kuat menyokong satu elemen } \\
\text { dibanding elemen lainya }\end{array}$ \\
\hline 7 & $\begin{array}{l}\text { Satu elemen jelas lebih } \\
\text { mutlak penting dari elemen } \\
\text { lainya }\end{array}$ & $\begin{array}{l}\text { Satu elemen yang kuat disokong dan dominan terlihat dalam } \\
\text { praktek }\end{array}$ \\
\hline 9 & $\begin{array}{l}\text { Satu elemen mutlak penting } \\
\text { daripada elemen lainnya }\end{array}$ & $\begin{array}{l}\text { Bukti yang mendukung elemen yang satu terhadap elemen } \\
\text { memiliki tingkat penegasan tertinggi yang mungkin menguatkan }\end{array}$ \\
\hline $\begin{array}{l}2,4 \\
6,8\end{array}$ & $\begin{array}{l}\text { Nilai - nilai antara antara } \\
\text { dua nilai pertimbangan yang } \\
\text { berdekatan }\end{array}$ & Nilai ini diberikan bila ada dua kompromi diantara dua pilihan. \\
\hline
\end{tabular}


2. Menormalisasi matriks keputusan dengan cara setiap kolom matriks dijumlahkan, lalu masing-masing kriteria pada matriks dibagi dengan nilai total kolomnya. Kemudian menentukan rata-rata baris matriks yang membuat himpunan sejumlah $\mathrm{n}$ bobot $\mathrm{w}$, yaitu $w 1, w 2, \ldots, w n$.

$\mathrm{W}: \mathrm{W}=\{\mathrm{W} 1, \mathrm{~W} 2, \ldots \mathrm{Wn}\}$.

Menorlmalkan tabel matriks berpasangan

$\sum_{i} a_{i j}=1$

Mencari vektor bobot dengan menghitung rata-rata untuk setiap baris

$w_{i}=\frac{1}{n} \sum_{j} a_{i j}$

3. Menentukan tingkat konsistensi dari matriks perbandingan berpasangan yang telah didapat dari langkah sebelumnya. Langkah-langkah yang dilakukan pada tahap ini adalah:

a. Mengalikan masing-masing nilai pada kolom pertama dengan prioritas relatif pada kriteria pertama, nilai pada kolom kedua dengan prioritas relatif pada kriteria kedua, dan seterusnya.

b. Menjumlahkan nilai pada setiap baris. Kemudian hasil penjumlahan tersebut dibagi dengan nilai kriteria prioritas relatif yang berkaitan.

c. Menjumlahkan hasil pada langkah poin (b) dengan banyaknya kriteria, kemudian disebut dengan $\lambda$ max.

d. Menghitung Consistency Index (CI) dengan persamaan 5.

$C I=(\lambda$ maks $-n) / n-1$

Dimana $\mathrm{n}$ adalah banyaknya kriteria.

e. Menghitung Consistency Ratio (CR) dengan persamaan 6 .

$C R=C I / C R$

4. IR adalah Indeks Random Consistency. Indeks Random Consistency dapat dilihat pada Tabel 2

Tabel 2 Tabel indeks random konsistensi

\begin{tabular}{|l|l|l|l|l|l|l|l|l|l|}
\hline $\mathrm{n}$ & 2 & 3 & 4 & 5 & 6 & 7 & 8 & 9 & 10 \\
\hline $\mathrm{RI}$ & 0 & 0.58 & 0.9 & 1.12 & 1.24 & 1.32 & 1.41 & 1.45 & 1.51 \\
\hline
\end{tabular}

Jika nilai $\mathrm{CR} \leq 0.1$, maka matriks perbandingan berpasangan dapat dikatakan konsisten dan bobot yang dihasilkan dapat digunakan untuk perangkingan alternatif dengan metode TOPSIS pada langkah selanjutnya pada penelitian ini.

\subsection{Technique for Order Preference by Similarity to Ideal Solution (TOPSIS)}

TOPSIS merupakan salah satu metode yang digunakan untuk mengambil keputusan dengan banyak kriteria. Metode ini pertama kali diperkenalkan oleh Yoo dan Hwang pada tahun 1981. Metode TOPSIS memiliki konsep dasar bahwa alternatif terpilih terbaik adalah alternatif yang memiliki jarak terpendek dari solusi ideal positif dan juga memiliki jarak terjauh dari solusi ideal negatif. (Kusrini \& Gole, 2007)

Langkah-langkah yang ada di metode TOPSIS adalah :

1. Membuat matriks keputusan ternormalisasi, metode TOPSIS memerlukan rating kinerja tiap alternatif (Siswa) pada setiap kriteria (Nilai kognitif siswa, Prestasi non Akademik, Jumlah kehadiran siswa, Nilai Sikap dan Jumlah Keterlambatan) yang ternormalisasi. Persamaan matriks ternormalisasi dapat dilihat pada persamaan 7 . (Kusrini \& Gole, 2007).

$$
r_{i j}=\frac{x_{i j}}{\sqrt{\sum_{i=1}^{m} x_{i j}}}
$$


Dengan $\mathrm{i}=1,2, \ldots, \mathrm{m} ;$ dan $\mathrm{j}=1,2, \ldots, \mathrm{n}$.

rij $=$ matriks keputusan ternormalisasi.

$\mathrm{xij}=$ bobot kriteria ke $\mathrm{j}$ pada alternatif ke $\mathrm{i}$.

$\mathrm{i}=$ alternatif peminatan ke $\mathrm{i}$.

$\mathrm{j}=$ kriteria peminatan ke $\mathrm{j}$.

2. Membuat matriks keputusan ternormalisasi terbobot

$$
V=\left[\begin{array}{ccc}
w_{11} r_{11} & \cdots & w_{1 n} r_{1 n} \\
\vdots & \ddots & \vdots \\
w_{m 1} r_{m 1} & \cdots & w_{n m} r_{n m}
\end{array}\right]
$$

Nilai matriks ternormalisasi terbobot dilambangkan dengan yij, dapat dihitung dengan persamaan 3.

$$
y_{i j}=w_{j} r_{i j}
$$

Dengan $\mathrm{i}=1,2, \ldots, \mathrm{m}$; dan $\mathrm{j}=1,2, \ldots, \mathrm{n}$. Di mana $w_{j}$ adalah bobot dari kriteria ke-j. Pemberian nilai bobot ditentukan oleh guru sebagai pengambil keputusan pemilihan siswa berprestasi di SMA Negeri 7 Surakarta. Pemberian bobot dengan memakai hasil dari perhitungan AHP sebelumnya.

3. Menentukan matriks solusi ideal positif dan matriks solusi ideal negative, dengan berdasarkan rating bobot ternormalisasi, maka dapat menentukan solusi ideal positif (A+) dan solusi ideal negatif (A-). Untuk dapat menentukan solusi ideal sebelumnya harus ditentukan apakah atribut bersifat keuntungan (benefit) atau bersifat biaya (cost).

Dimana,

$$
\begin{aligned}
& A^{+}=\left(y_{i}^{+}, y_{2}^{+}, \ldots, y_{2 n}^{+}\right) \\
& A^{-}=\left(y_{i}^{-}, y_{2}^{-}, \ldots, y_{2 n}^{-}\right)
\end{aligned}
$$

$$
\begin{aligned}
& y_{j}^{+}=\left\{\begin{array}{c}
\max _{i} y_{i j} \text { jika adalah atribut keuntungan } \\
\max _{i} y_{i j} \text { jika adalah atribut biaya }
\end{array}\right. \\
& y_{j}^{-}=\left\{\begin{array}{c}
\max _{i} y_{i j} \text { jika adalah atribut keuntungan } \\
\max _{i} y_{i j} \text { jika adalah atribut biaya }
\end{array}\right.
\end{aligned}
$$

Atribut keuntungan (benefit) adalah atribut yang diberikan kepada nilai tertinggi untuk mendapatkan jarak terdekat dengan solusi ideal positif dan sedangkan untuk jarak terjauh dengan menggunakan solusi ideal negatif. Sebaliknya, atribut biaya (cost) adalah atribut yang diberikan kepada nilai terkecil untuk mendapatkan jarak terjauh dari solusi ideal positif dan jarak terdekat dari solusi ideal negatif.

${ }_{j}^{+}$adalah nilai terbesar dari matriks y pada tiap kriteria ke $\mathrm{j}$
$y_{j}^{-}$.adalah nilai terkecil dari matriks y pada tiap kriteria ke $\mathrm{j}$.

4. Menentukan jarak antara nilai setiap alternatif (siswa) dengan matriks solusi ideal positif dan solusi ideal negatif. Jarak antara nilai alternatif ke i dengan solusi ideal positif dapat dirumuskan dengan persamaan 12 , dan jarak antara nilai alternatif ke i dengan solusi ideal negatif dapat dirumuskan dengan persamaan 13.

$$
\begin{aligned}
& D_{i}^{+}=\sqrt{\sum_{j=1}^{n}\left(y_{j}^{+}-y_{i j}\right)^{2}} \\
& D_{i}^{-}=\sqrt{\sum_{j=1}^{n}}\left(y_{i j}-y_{i}^{-}\right)^{2}
\end{aligned}
$$

$D_{i}^{+}$adalah jarak antara nilai alternatif ke i dengan solusi ideal positif.

$D_{i}^{-}$adalah jarak antara nilai alternatif ke i dengan solusi ideal negatif. 
5. Tahap ini adalah menentukan nilai preferensi untuk setiap alternative, nilai preferensi (Vi) terbesar menunjukkan alternatif ke i dan merupakan nilai yang lebih layak untuk dipilih sebagai solusi terbaik. Nilai Vi dapat dihitung dengan persamaan 14.

$$
V_{i}=\frac{D_{i}^{-}}{D_{j}^{-}-D_{j}^{+}}
$$

$D_{i}^{+}$adalah jarak antara nilai alternatif ke i dengan solusi ideal positif.

$D_{i}^{-}$adalah jarak antara nilai alternatif ke i dengan solusi ideal negatif.

$V_{i}$ adalah nilai preferensi yang menunjukkan nilai dari alternatif ke i atau solusi pemilihan siswa berprestasi. Setelah didapat nilai, maka alternatif akan dirangking berdasarkan urutan nilai.

Nilai terbesar dari menunjukkan bahwa alternatif ke i adalah solusi yang paling disarankan.

\section{METODE PENELITIAN}

\subsection{Teknik Pengumpulan Data}

Teknik Pengumpulan Data pada penelitian ini adalah melakukan observasi di SMA N 7 Surakarta pada proses seleksi pemilihan siswa berprestasi, melakukan wawancara dengan narasumber (Panitia seleksi, Kepala Sekolah) di SMA N 7 Surakarta dan melakukan studi pustaka terkait dengan metode yang dipergunakan yaitu AHP dan TOPSIS, perancangan sistem dengan pendekatan Object Oriented, serta bahasa pemrograman yang dipergunakan untuk membuat aplikasi ini.

\subsection{Perancangan Sistem}

Perancangan sistem pada penelitian ini menggunakan pendekatan Object oriented, adapun diagram yang gunakan adalah Use Case Diagram, Activity Diagram, Class Diagram, Squence Diagram, Desain Input Output, Desain Database

\section{HASIL DAN PEMBAHASAN}

\subsection{Rancangan Pendukung Keputusan}

Metode AHP digunakan untuk melakukan proses perhitungan bobot prioritas, yang akan digunakan didalam proses perangkingan alternatif pada metode TOPSIS. Sistem mendapatkan inputan dari pengguna sistem berupa data hasil penilaian Siswa berprestasi, data siswa berprestasi terdiri dari 33 siswa, sedangkan data nilai matriks perbandingan berpasangan terdiri dari 5 kriteria yaitu Kehadiran (C1), Keterlambatan (C2), Prestasi (C3), Nilai Kognitif (C4), Nilai Sikap (C5).

\section{a. Metode AHP}

1. Menentukan bobot kepentingan dari tiap-tiap kriteria yang ada.

2. Membuat tabel perbandingan prioritas tiap kriteria yang ada, penentuan skala kepentingan menggunakan Skala Penilaian Perbandingan Berpasangan dengan menggunakan skala Saaty.

$$
\left[\begin{array}{ccccc}
1 & 1 & 0,5 & 0,5 & 0,33 \\
\frac{1}{1} & 1 & 0,5 & 0,5 & 0,33 \\
\frac{1}{0,5} & \frac{1}{0,5} & 1 & 1 & 0,5 \\
\frac{1}{0,5} & \frac{1}{0,5} & \frac{1}{1} & 1 & 0,5 \\
\frac{1}{0,33} & \frac{1}{0,33} & \frac{1}{0,5} & \frac{1}{0,5} & 1
\end{array}\right]=\left[\begin{array}{ccccc}
1 & 1 & 0,5 & 0,5 & 0,33 \\
1 & 1 & 0,5 & 0,5 & 0,33 \\
2 & 2 & 1 & 1 & 0,5 \\
2 & 2 & 1 & 1 & 0,5 \\
3 & 3 & 2 & 2 & 1
\end{array}\right]
$$

Tabel 3 merupakan hasil perbandingan prioritas tiap kriteria. 
Tabel 3 Perbandingan prioritas tiap kriteria

\begin{tabular}{|l|c|c|c|c|c|}
\hline & Kehadiran & Keterlambatan & Prestasi & Nilai Kognitif & Nilai Sikap \\
\hline Kehadiran & 1 & 1 & 0.5 & 0.5 & 0.33 \\
\hline Keterlambatan & $1 / 1$ & 1 & 0.5 & 0.5 & 0.33 \\
\hline Prestasi & $1 / 0.5$ & $1 / 0.5$ & 1 & 1 & 0.5 \\
\hline Nilai Kognitif & $1 / 0.5$ & $1 / 0.5$ & $1 / 1$ & 1 & 0.5 \\
\hline Nilai Sikap & $1 / 0.33$ & $1 / 0.33$ & $1 / 0.5$ & $1 / 0.5$ & 1 \\
\hline
\end{tabular}

Tahap selanjutnya adalah mengubah nilai yang ada pada Tabel 4 menjadi nilai desimal seperti pada Tabel 4.

Tabel 4 Perbandingan prioritas tiap kriteria

\begin{tabular}{|l|c|c|c|c|c|}
\hline & Kehadiran & Keterlambatan & Prestasi & Nilai Kognitif & Nilai Sikap \\
\hline Kehadiran & 1 & 1 & 0.5 & 0.5 & 0.33 \\
\hline Keterlambatan & 1 & 1 & 0.5 & 0.5 & 0.33 \\
\hline Prestasi & 2 & 2 & 1 & 1 & 0.5 \\
\hline Nilai Kognitif & 2 & 2 & 1 & 1 & 0.5 \\
\hline Nilai Sikap & 3 & 3 & 2 & 2 & 1 \\
\hline Jumlah & 9 & 9 & 5 & 5 & 2.67 \\
\hline
\end{tabular}

3. Lakukan normalisasi tabel perbandingan prioritas, Didapat dari pembagian tiap sel dibagi dengan jumlah tiap kolomnya, dengan menggunakan persamaan 4

$$
\left[\begin{array}{c}
\left(\frac{1}{9}\right)+\left(\frac{1}{9}\right)+\left(\frac{0,5}{5}\right)+\left(\frac{0,5}{5}\right)+\left(\frac{0,33}{2,67}\right) \\
\left(\frac{1}{9}\right)+\left(\frac{1}{9}\right)+\left(\frac{0,5}{5}\right)+\left(\frac{0,5}{5}\right)+\left(\frac{0,33}{2,67}\right) \\
\left(\frac{2}{9}\right)+\left(\frac{2}{9}\right)+\left(\frac{1}{5}\right)+\left(\frac{1}{5}\right)+\left(\frac{0,5}{2,67}\right) \\
\left(\frac{2}{9}\right)+\left(\frac{2}{9}\right)+\left(\frac{1}{5}\right)+\left(\frac{1}{5}\right)+\left(\frac{0,5}{2,67}\right) \\
\left(\frac{3}{9}\right)+\left(\frac{3}{9}\right)+\left(\frac{2}{5}\right)+\left(\frac{2}{5}\right)+\left(\frac{1}{2,67}\right)
\end{array}\right] / 5
$$

$\left|\begin{array}{l}0.11+0.11+0.10+0.10+0.13 \\ 0.11+0.11+0.10+0.10+0.13 \\ 0.22+0.22+0.20+0.20+0.19 \\ 0.22+0.22+0.20+0.20+0.19 \\ 0.33+0.33+0.40+0.40+0.38\end{array}\right| / 5=\left|\begin{array}{l}0.1 \\ 0.1 \\ 0.2 \\ 0.2 \\ 0.4\end{array}\right|$

Kehadiran $=\{(1 / 9)+(1 / 9)+(0,5 / 5)+(0,5 / 5)+(0,33 / 2,67)\} / 5=\{0,11+0,11+0,10+0,10+0,13\} / 5=0,1$ Keterlambatan $=\{(1 / 9)+(1 / 9)+(0,5 / 5)+(0,5 / 5)+(0,33 / 2,67)\} / 5=\{0,11+0,11+0,10+0,10+0,13\} / 5=0,1$ Prestasi $=\{(2 / 9)+(2 / 9)+(1 / 5)+(1 / 5)+(0,5 / 2,67)\} / 5=\{0,22+0,22+0,20+0,20+0,19\} / 5=0,2$

Nilai Kognitif $=\{(2 / 9)+(2 / 9)+(1 / 5)+(1 / 5)+(0,5 / 2,67)\} / 5=\{0,22+0,22+0,20+0,20+0,19\} / 5=0,2$ Nilai Sikap $=\{(3 / 9)+(3 / 9)+(2 / 5)+(2 / 5)+(1 / 2,67)\} / 5=\{0,33+0,33+0,40+0,40+0,38\} / 5=0,4$ setelah dihitung berikut hasil normalisasi perbandingan prioritas pada Tabel 6 .

Tabel 5 Normalisasi tabel perbandingan prioritas

\begin{tabular}{|l|r|r|r|r|r|}
\hline & \multicolumn{1}{|c|}{ Kehadiran } & \multicolumn{1}{|c|}{ Keterlambatan } & \multicolumn{1}{l|}{ Prestasi } & \multicolumn{1}{l|}{ Nilai Kognitif } & Nilai Sikap \\
\hline Kehadiran & 0.11 & 0.11 & 0.1 & 0.1 & 0.13 \\
\hline Keterlambatan & 0.11 & 0.11 & 0.1 & 0.1 & 0.13 \\
\hline Prestasi & 0.22 & 0.22 & 0.2 & 0.2 & 0.19 \\
\hline Nilai Kognitif & 0.22 & 0.22 & 0.2 & 0.2 & 0.19 \\
\hline Nilai Sikap & 0.33 & 0.33 & 0.4 & 0.4 & 0.38 \\
\hline Jumlah & 1 & 1 & 1 & 1 & 1 \\
\hline
\end{tabular}

4. Menentukan nilai konsistensi untuk mengetahui apakah sudah konsisten atau tidak

Menghitung principal eigen value atau $K$ max Tabel 5 dengan cara menjumlahkan hasil perkalian antara sel pada baris jumlah dan sel pada kolom Priority Vector. Misalkan A adalah matriks dan w adalah vektor bobot. 


$$
(A)\left(w^{T}\right)=\left[\begin{array}{ccccc}
1 & 1 & 0,5 & 0,5 & 0,33 \\
\frac{1}{1} & 1 & 0,5 & 0,5 & 0,33 \\
\frac{1}{0,5} & \frac{1}{0,5} & 1 & 1 & 0,5 \\
\frac{1}{0,5} & \frac{1}{0,5} & \frac{1}{1} & 1 & 0,5 \\
\frac{1}{0,33} & \frac{1}{0,33} & \frac{1}{0,5} & \frac{1}{0,5} & 1
\end{array}\right] \times\left[\begin{array}{l}
0,1 \\
0,1 \\
0,2 \\
0,2 \\
0,4
\end{array}\right]=\left[\begin{array}{l}
0,55 \\
0,55 \\
1,03 \\
1,03 \\
1,85
\end{array}\right]
$$

$$
\Lambda \max =\frac{1}{n} \sum_{i=1}^{n}\left[\frac{\text { elemen } k e-i p a d a(A)\left(w^{T}\right)}{\text { elemen } k e-i p a d a w^{T}}\right] \rightarrow=\frac{1}{5}\left[\frac{0,55}{0,1}+\frac{0,55}{0,1}+\frac{1,03}{0,2}+\frac{1,03}{0,2}+\frac{1,85}{0,4}\right]=5,0101
$$

Menghitung indeks konsistensi: $\mathrm{CI}=(\Lambda \max -\mathrm{n}) /(\mathrm{n}-1)$ dimana $\Lambda$ adalah nilai eigen terbesar dari matrik berordo $\mathrm{n}$ dan $\mathrm{n}$ adalah jumlah kriteria

$\mathrm{CI}=($ Kmax $-\mathrm{n}) /(\mathrm{n}-1)=(5,01-5) /(5-1)=0 / 4=0,0033140$

$\mathrm{CI}=0$ artinya pembobotan yang dilakukan sangat konsisten

Menghitung Rasio Konsistensi (CR) dimana, Consistency Index (CI) untuk n $=5$.

Diperoleh RI5 $=1,12$ seperti pada Tabel 7 .

Sehingga: $\mathrm{CR}=\mathrm{CI} / \mathrm{RI}=-(0,0033140) / 1,12=0,0029589$

Tabel 6. Tabel RI (Random Index)

\begin{tabular}{|l|l|l|l|l|l|l|l|l|l|}
\hline $\mathrm{n}$ & 2 & 3 & 4 & 5 & 6 & 7 & 8 & 9 & 10 \\
\hline $\mathrm{RI}$ & 0 & 0.58 & 0.9 & 1.12 & 1.24 & 1.32 & 1.41 & 1.45 & 1.51 \\
\hline
\end{tabular}

Jika $\mathrm{CI}=0$ Maka sangat konsisten; jika $\mathrm{CI} /(\mathrm{RI}) \_\mathrm{n} \leq 0,1$ maka cukup konsisten, dan jika $\mathrm{CI} /(\mathrm{RI}) \_\mathrm{n} \geq 0,1$ maka A sangat tidak konsisten.

\section{b. Metode TOPSIS}

Metode TOPSIS digunakan untuk perangkingan alternative, langkah-langkah pada metode TOPSIS adalah Menentukan rating kecocokan pada tiap Alternatif data nilai rapor keempat siswa yang digunakan. Tabel 7 berikut ini merupakan contoh kasus sebagai simulasi penghitungan.

Tabel 7. Contoh Kasus

\begin{tabular}{|c|c|l|c|c|c|c|}
\hline NIS & Siswa & Kehadiran & Keterlambatan & Prestasi & $\begin{array}{c}\text { Nilai } \\
\text { Kognitif }\end{array}$ & $\begin{array}{c}\text { Nilai Sikap, } \\
\text { Spiritual \& Sosial }\end{array}$ \\
\hline 6933 & Siswa 1 & 0x Tanpa Ket & 1 & Tidak ada & 78,1 & B dan B \\
\hline 6936 & Siswa 2 & 2x Tanpa Ket & 1 & Provinsi & 80,8 & B dan A \\
\hline 6966 & Siswa 3 & 13x Tanpa Ket & 3 & Kabupaten & 80 & A dan A \\
\hline 6967 & Siswa 4 & 0x Tanpa Ket & 5 & Nasional & 80,3 & A dan B \\
\hline
\end{tabular}

Tabel 8 Rating pada setiap alternatif

\begin{tabular}{|l|l|c|c|c|c|}
\hline \multicolumn{1}{|c|}{ Siswa } & Kehadiran & Keterlambatan & Prestasi & Nilai Kognitif & Nilai Sikap, \\
\hline Siswa 1 & 1 & 1 & 5 & 8 & 6 \\
\hline Siswa 2 & 3 & 1 & 8 & 8 & 9 \\
\hline Siswa 3 & 10 & 1 & 7 & 8 & 10 \\
\hline Siswa 4 & 1 & 1 & 9 & 8 & 9 \\
\hline
\end{tabular}


1)Membuat matriks keputusan ternormalisasi dengan rumus persamaan 7. Adapun caranya adalah nilai setiap kriteria dipangkatkan 2 lalu dijumlah perkolom sesuai dengan nilai setiap kriteria , setelah itu hasil dari jumlah di akar,dengan menggunakan persamaan (7) seperti yang tersaji pada perhitungan berikut ini:

\begin{tabular}{|c|c|c|}
\hline $\begin{array}{l}\text { Kehadiran } \\
\begin{array}{l}\left|x_{1}\right|=\sqrt{1^{2}+3^{2}+10^{2}+1^{2}}=10,5 \\
r_{11}=\frac{x_{11}}{\left|x_{1}\right|}=\frac{1}{10,5}=0,09 \\
r_{21}=\frac{x_{21}}{\left|x_{1}\right|}=\frac{3}{10,5}=0,28 \\
r_{31}=\frac{x_{11}}{\mid x_{1 \mid}}=\frac{10}{10,5}=0,95 \\
r_{41}=\frac{x_{21}}{\left|x_{1}\right|}=\frac{1}{10,5}=0,09\end{array}\end{array}$ & $\begin{array}{l}\text { Keterlambatan } \\
\left|x_{2}\right|=\sqrt{1^{2}+1^{2}+1^{2}+1^{2}}=2 \\
r_{12}=\frac{x_{11}}{\left|x_{2}\right|}=\frac{1}{2}=0,5 \\
r_{22}=\frac{x_{21}}{\left|x_{2}\right|}=\frac{1}{2}=0,5 \\
r_{32}=\frac{x_{11}}{\left|x_{2}\right|}=\frac{1}{2}=0,5 \\
r_{42}=\frac{x_{21}}{\mid x_{21}}=\frac{1}{2}=0,5\end{array}$ & $\begin{array}{l}\text { Prestasi } \\
\left|x_{3}\right|=\sqrt{5^{2}+8^{2}+7^{2}+9^{2}}=14,8 \\
r_{13}=\frac{x_{11}}{\left|x_{3}\right|}=\frac{5}{14,8}=0,34 \\
r_{23}=\frac{x_{21}}{\mid x_{3 \mid}}=\frac{8}{14,8}=0,54 \\
r_{33}=\frac{x_{11}}{\left|x_{3}\right|}=\frac{7}{14,8}=0,47 \\
r_{43}=\frac{x_{21}}{\left|x_{3}\right|}=\frac{9}{14,8}=0,61\end{array}$ \\
\hline $\begin{array}{l}\text { Nilai sikap } \\
\left|x_{5}\right|=\sqrt{6^{2}+9^{2}+10^{2}+9^{2}}=17,3 \\
r_{15}=\frac{x_{11}}{\left|x_{5}\right|}=\frac{6}{17,3}=0,35 \\
r_{25}=\frac{x_{21}}{\left|x_{5}\right|}=\frac{9}{17,3}=0,52 \\
r_{35}=\frac{x_{11}}{\left|x_{5}\right|}=\frac{10}{17,3}=0,58 \\
r_{45}=\frac{x_{21}}{\left|x_{5}\right|}=\frac{9}{17,3}=0,52\end{array}$ & $\begin{array}{l}\text { Nilai kognitif } \\
\left|x_{4}\right|=\sqrt{8^{2}+8^{2}+8^{2}+8^{2}}=16 \\
r_{14}=\frac{x_{11}}{\left|x_{4}\right|}=\frac{8}{16}=0,5 \\
r_{24}=\frac{x_{21}}{\left|x_{4}\right|}=\frac{8}{16}=0,5 \\
r_{34}=\frac{x_{11}}{\left|x_{4}\right|}=\frac{8}{16}=0,5 \\
r_{44}=\frac{x_{21}}{\left|x_{4}\right|}=\frac{8}{16}=0,5\end{array}$ & \\
\hline
\end{tabular}

Kemudian nilai dari setiap kriteria pada matriks keputusan dibagi dengan akar setiap kriteria sehingga menghasilkan matrik keputusan ternomalisasi seperti tersaji pada Tabel 9.

Tabel 9 Tabel matriks keputusan ternormalisasi (R)

\begin{tabular}{|l|l|c|c|c|c|}
\hline \multicolumn{1}{|c|}{ Siswa } & Kehadiran & Keterlambatan & Prestasi & Nilai Kognitif & Nilai Sikap, \\
\hline Siswa 1 & 0.09 & 0.5 & 0.34 & 0.5 & 0.35 \\
\hline Siswa 2 & 0.28 & 0.5 & 0.54 & 0.5 & 0.52 \\
\hline Siswa 3 & 0.95 & 0.5 & 0.47 & 0.5 & 0.58 \\
\hline Siswa 4 & 0.09 & 0.5 & 0.61 & 0.5 & 0.52 \\
\hline
\end{tabular}

2)Membuat matriks normalisasi terbobot. Untuk menghitung matriks normalisasi terbobot menggunakan persamaan 8

$$
V=\left[\begin{array}{lllll}
(0,1)(0,09) & (0,1)(0,50) & (0,2)(0,34) & (0,2)(0,10) & (0,4)(0,35) \\
(0,1)(0,28) & (0,1)(0,50) & (0,2)(0,54) & (0,2)(0,10) & (0,4)(0,52) \\
(0,1)(0,95) & (0,1)(0,50) & (0,2)(0,47) & (0,2)(0,10) & (0,4)(0,58) \\
(0,1)(0,09) & (0,1)(0,50) & (0,2)(0,61) & (0,2)(0,10) & (0,4)(0,52)
\end{array}\right]
$$




$$
=\left[\begin{array}{lllll}
0,01 & 0,05 & 0,07 & 0,10 & 0,13 \\
0,03 & 0,05 & 0,11 & 0,10 & 0,19 \\
0,10 & 0,05 & 0,10 & 0,10 & 0,21 \\
0,01 & 0,05 & 0,13 & 0,10 & 0,19
\end{array}\right]
$$

3) Mencari Nilai solusi ideal positif dan solusi ideal negatif. Dengan berdasarkan rating bobot ternormalisasi maka dapat menentukan solusi ideal positif $(\mathrm{A}+)$ menggunakan rumus 9 dan solusi ideal negatif (A-) menggunakan rumus 2.5

$A^{+}=\left\{\left(\max v_{i j} \mid j \in J\right)\left(\min v_{i j} \mid j \in J^{\prime}\right), i=1,2,3, \ldots m\right\}=\left\{v_{1}^{+}, v_{2}^{+}, \ldots v_{m}^{+}\right\}$

$A^{-}=\left\{\left(\max v_{i j} \mid j \in J\right)\left(\min v_{i j} \mid j \in J^{\prime}\right), i=1,2,3, \ldots m\right\}=\left\{v_{1}^{-}, v_{2}^{-}, \ldots v_{m}^{-}\right\}$

$A^{+}=\{0,10 ; 0,05 ; 0,13 ; 0,10 ; 0,21\}$

$A^{-}=\{0,01 ; 0,05 ; 0,07 ; 0,10 ; 0,13\}$

Menentukan jarak alternatif Ai antara nilai setiap alternatif (Siswa) dengan solusi ideal positif dengan menggunakan rumus 11 dan solusi ideal negative dengan menggunakan Persamaan 11 dan persamaan 12

Solusi Ideal Positif

$$
\begin{aligned}
& D_{i}^{+}=\sqrt{\begin{array}{c}
(0,01-0,10)^{2}+(0,05-0,05)^{2}+(0,07-0,13)^{2} \\
+(0,10-0,10)^{2}+(0,13-0,21)^{2}
\end{array}=0,02} \quad \begin{array}{c}
\text { Maka diperoleh nilai solusi } \\
\text { idea positif sebagai berikut : } \\
D_{1^{+}}=\text {Siswa } 1=0,02 \\
D_{2^{+}}=\text {Siswa } 2=0,01 \\
D_{3^{+}}=\text {Siswa } 3=0,0 \\
D_{4^{+}}=\text {Siswa } 4=0,01
\end{array} \\
& D_{2^{+}}=\sqrt{\begin{array}{c}
(0,03-0,10)^{2}+(0,05-0,05)^{2}(0,11-0,13)^{2} \\
+(0,10-0,10)^{2}+(0,19-0,21)^{2}
\end{array}=0,01}
\end{aligned}
$$

Solusi Idea Negatif

$$
\begin{aligned}
& D_{1^{-}}=\sqrt{\begin{array}{c}
(0,01-0,01)^{2}+(0,05-0,05)^{2}+(0,07-0,07)^{2} \\
+(0,10-0,10)^{2}+(0,13-0,13)^{2}
\end{array}=0,00} \\
& D_{2^{-}}=\sqrt{\begin{array}{c}
(0,03-0,01)^{2}+(0,05-0,05)^{2}(0,11-0,07)^{2} \\
+(0,10-0,10)^{2}+(0,19-0,13)^{2}
\end{array}}=0,01
\end{aligned} \longrightarrow \begin{aligned}
& \text { Maka diperoleh nilai solusi } \\
& \text { idea negatif sebagai berikut } \\
& D_{1^{-}}=\text {Siswa } \begin{array}{c}
=0,00 \\
D_{2^{-}}=\text {Siswa } 2=0,01
\end{array} \\
& D_{3^{-}}=\text {Siswa } 3=0,02 \\
& D_{4^{-}}=\text {Siswa } 4=0,01
\end{aligned}
$$$$
D_{4^{-}}=\sqrt{\begin{array}{c}
(0,01-0,01)^{2}+(0,05-0,05)^{2}+(0,13-0,07)^{2} \\
+(0,10-0,10)^{2}+(0,91-0,13)^{2}
\end{array}}=0,01
$$

4) Menentukan nilai preferensi untuk setiap alternatif Nilai preferensi menggunakan persamaan14

$$
\begin{aligned}
& V_{1} \text { Siswa } 1=\frac{0,0}{0,0+0,02}=0,0 \\
& V_{2} \text { Siswa } 2=\frac{0,01}{0,01+0,02}=0,33
\end{aligned}
$$

$$
\begin{aligned}
& V_{3} \text { Siswa3 }=\frac{0,02}{0,02+0}=1 \\
& V_{4} \text { Siswa4 }=\frac{0,01}{0,01+0,01}=0,5
\end{aligned}
$$


5) Berdasarkan perhitungan diatas, maka langkah terakhir adalah melakukan pengurutan dengan nilai yang paling besar terlebih dahulu, maka didapat Siswa3 dengan nilai 1, Siswa4 dengan nilai 0.5 , Siswa2 dengan nilai 0.33 dan terakhir adalah Siswa1 dengan nilai 0. Hasil pemilihan siswa berprestasi di SMA N 7 dengan menggunakan Metode AHP dan TOPSIS adalah siswa Siswa3. Selanjutnya akan menjadi pertimbangan Kepala Sekolah seperti pada tabel 10.

Tabel 10 Hasil Nilai Topsis

\begin{tabular}{|l|l|l|}
\hline Siswa & Rangking & Nilai \\
\hline Siswa 3 & 1 & 1 \\
\hline Siswa 4 & 2 & 0.5 \\
\hline Siswa 2 & 3 & 0.33 \\
\hline Siswa 1 & 4 & 0 \\
\hline
\end{tabular}

\subsection{Perancangan Sistem}

Perancangan sistem dengan menggunakan UML (Unified Modeling Language), adapun diagram yang dipergunakan meliputi Use Case Diagram, Activity Diagram, class diagram, squence diagram dan perancangan database.

Use case diagram menggambarkan proses sistem (kebutuhan sistem dari sudut pandang user). Use case Diagram pemilihan siswa berprestasi seperti pada Gambar 1.

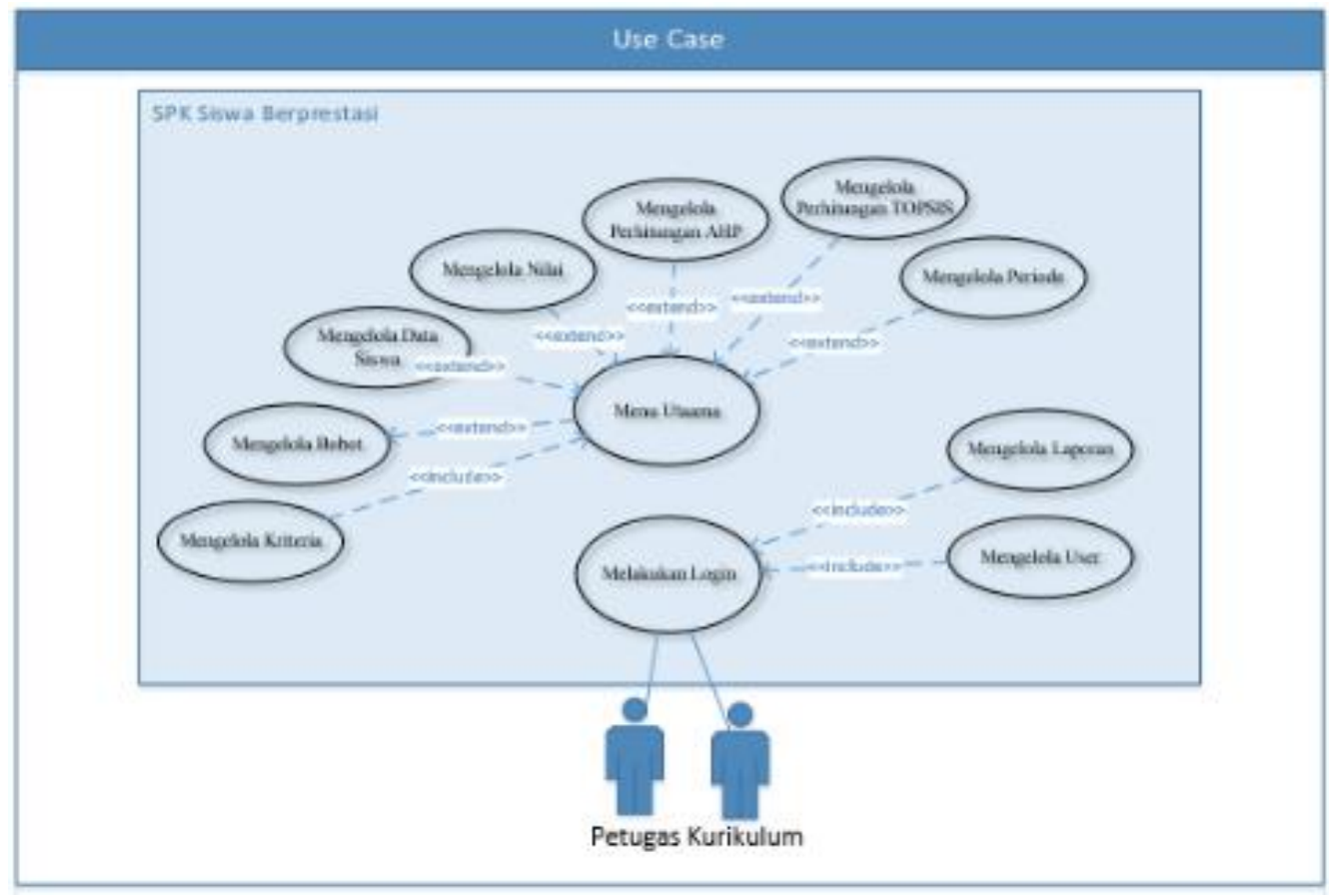

Gambar 1. Use case Diagram pemilihan siswa berprestasi

Activity diagram ini berfungsi untuk melakukan proses perhitungan algoritma AHP dan TOPSIS. Cara kerjanya adalah Kurikulum melakukan login kemudian memilih menu perhitungan, kemudia pilih periode dan tekan button hitung. Activity diagram mengelola perhitungan dapat dilihat pada Gambar 2. 


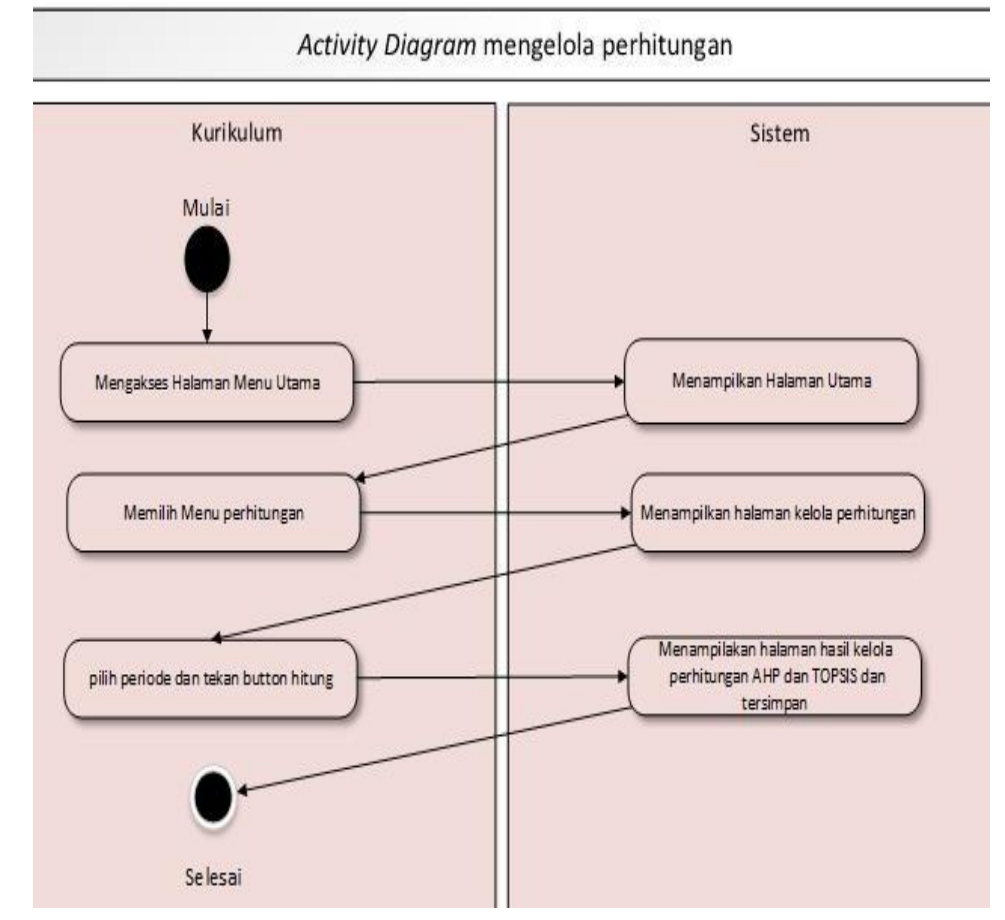

Gambar 2 Activity diagram mengelola perhitungan

Sequence diagram digunakan untuk memodelkan aliran logika dalam sebuah sistem dengan cara yang visual. Sequence diagram pemilihan siswa berprestasi seperti pada Gambar 3 .

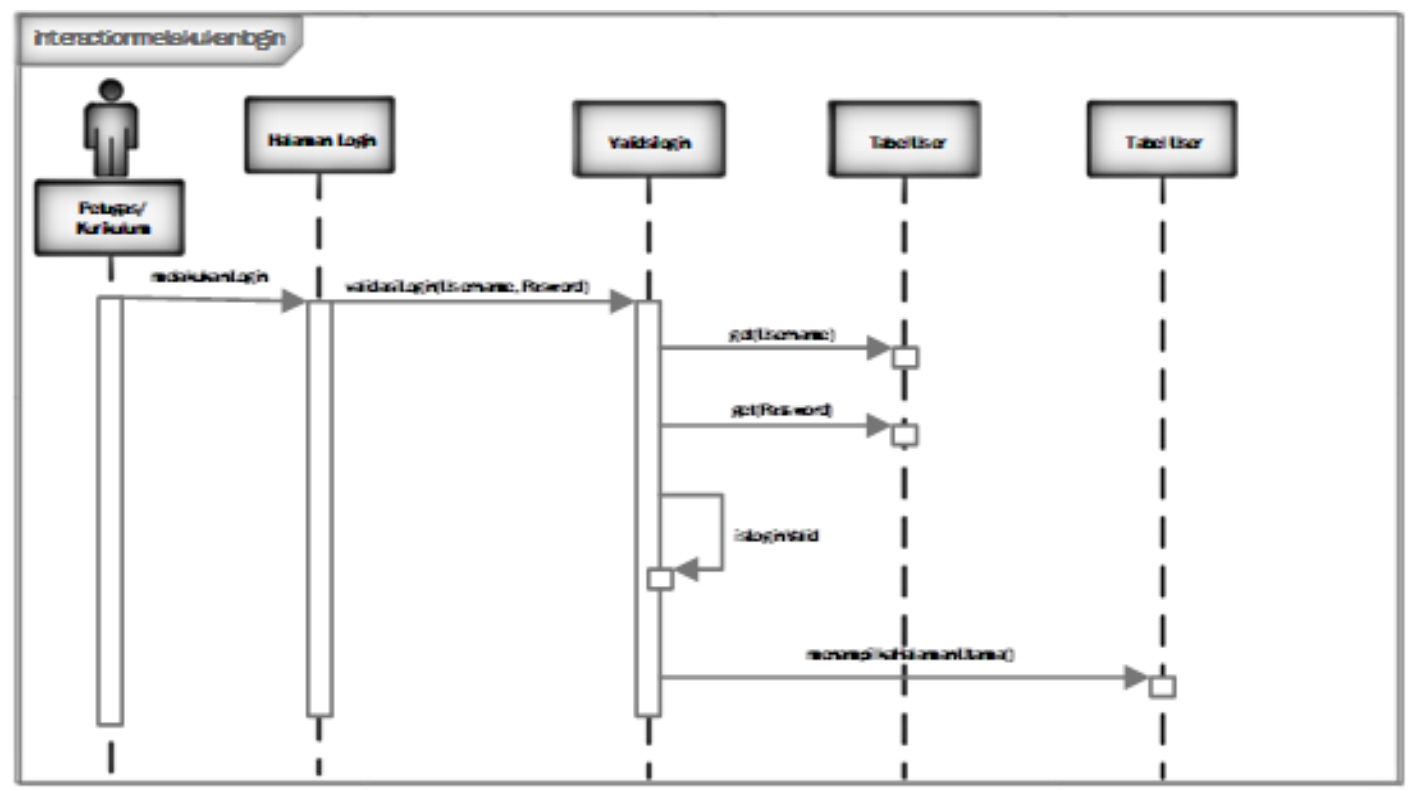

Gambar 3 Sequence diagram nilai alternatif

Class diagram adalah diagram yang dipergunakan untuk menampilkan beberapa kelas serta paket-paket yang ada dalam sistem yang sedang kita gunakan. Class diagram memberi gambaran (diagram statis) tentang sistem/perangkat lunak dan relas-relasi yang ada didalamnya. Class diagram dan relasi tabel sistem pemilihan siswa berprestasi adalah pada Gambar 4. 


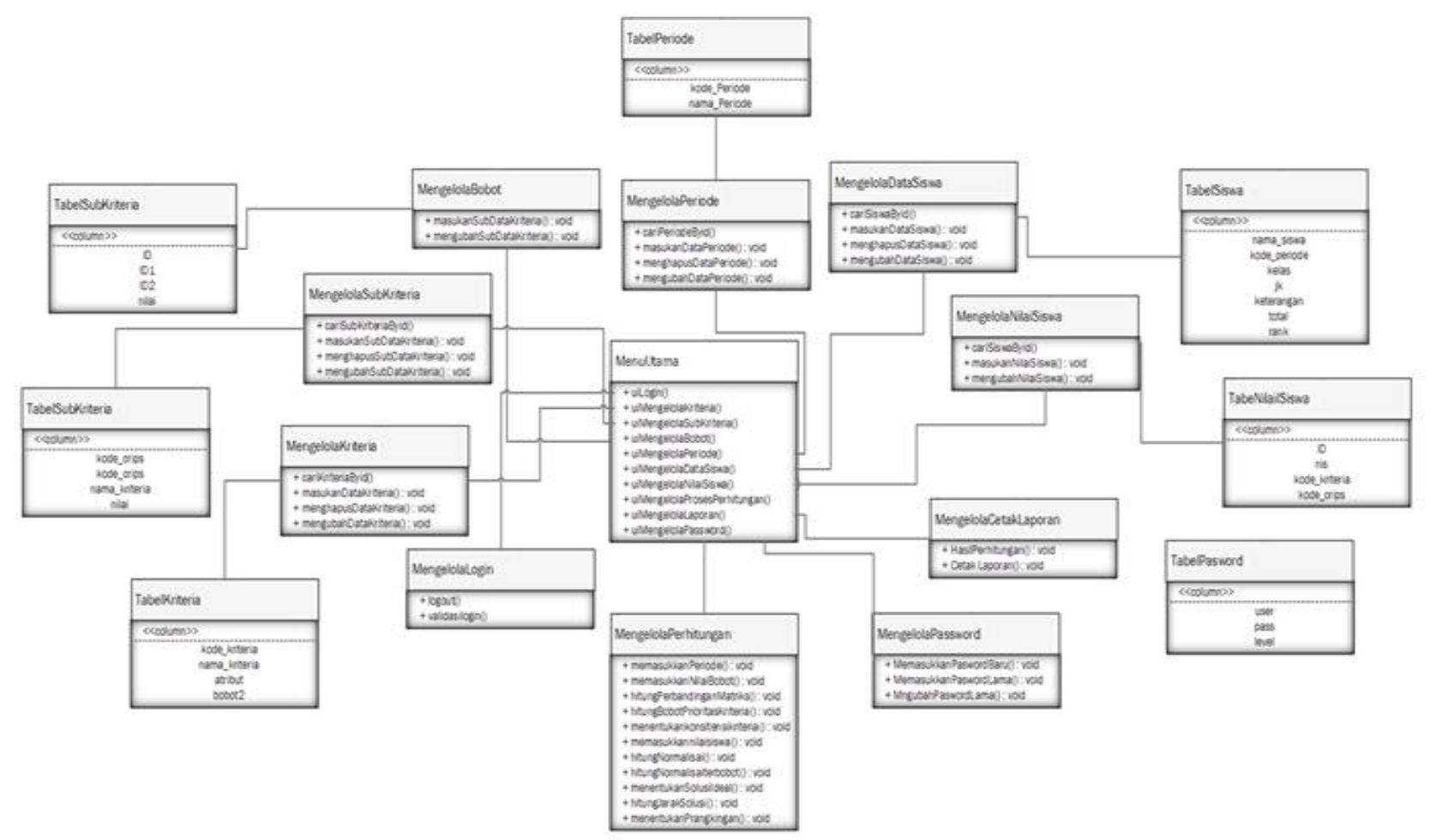

\subsection{Implementasi Sistem}

Gambar 4 Class Diagram

Tahapan implementasi sistem merupakan tahap terakhir dari pengembangan sistem SDLC (System Development Life Cycle) dengan Metode Waterfall. Aplikasi yang sudah berhasil dibuat terdiri dari: (1) Halaman login dibuat untuk memberi fasilitas terhadap pengguna sistem pendukung keputusan ini, sehingga pengguna dapat mengakses sistem sesuai dengan levelnya. (2) Halaman utama ini memberikan sambutan terhadap pengguna dan menjelaskan mengenai sistem pendukung keputusan dengan menggunakan metode AHP dan TOPSIS. (3) Halaman awal kriteria akan di sajikan tabel yang berisi kriteria dari setiap alternatif yang sudah diinputkan didalam sistem dengan tujuan untuk pengambilan keputusan. (4) Halaman bobot kriteria untuk menampilkan tabel perbandingan berpasangan dalam sistem perhitungan AHP untuk menentukan tingkat kepentingan antar masing masing kriteria. (5) Halaman data siswa pada Gambar 5 akan disajikan tabel yang berisikan semua data calon siswa yang sudah dimasukan kedalam sistem, dan data ini yang diolah admin selaku pemegang hak akses seperti menambahkan, mengubah, menghapus dan mencetak.

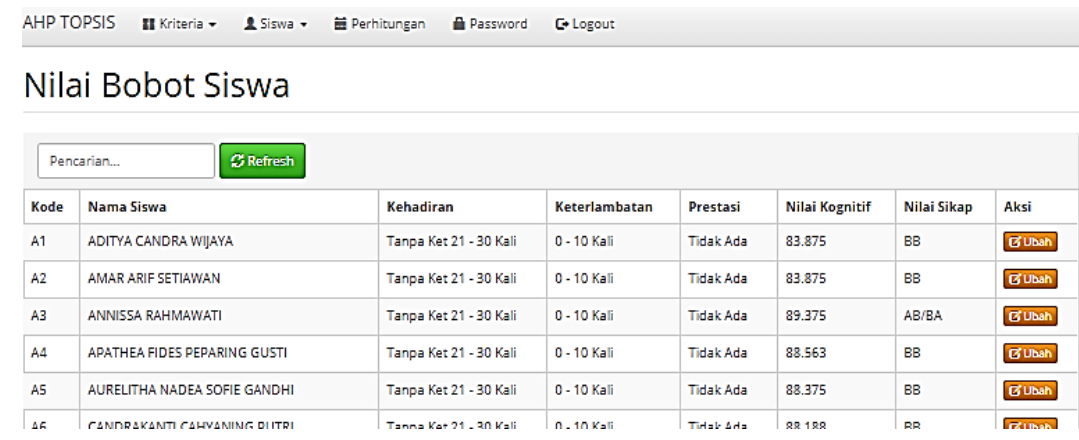

Gambar 5. Halaman Data Siswa 
(6) Laporan cetak perhitungan ini menampilkan laporan dengan versi print out atau cetak hasil seleksi siswa berprestasi. Laporan hasil perhitungan seleksi siswa berprestasi seperti Gambar 6.

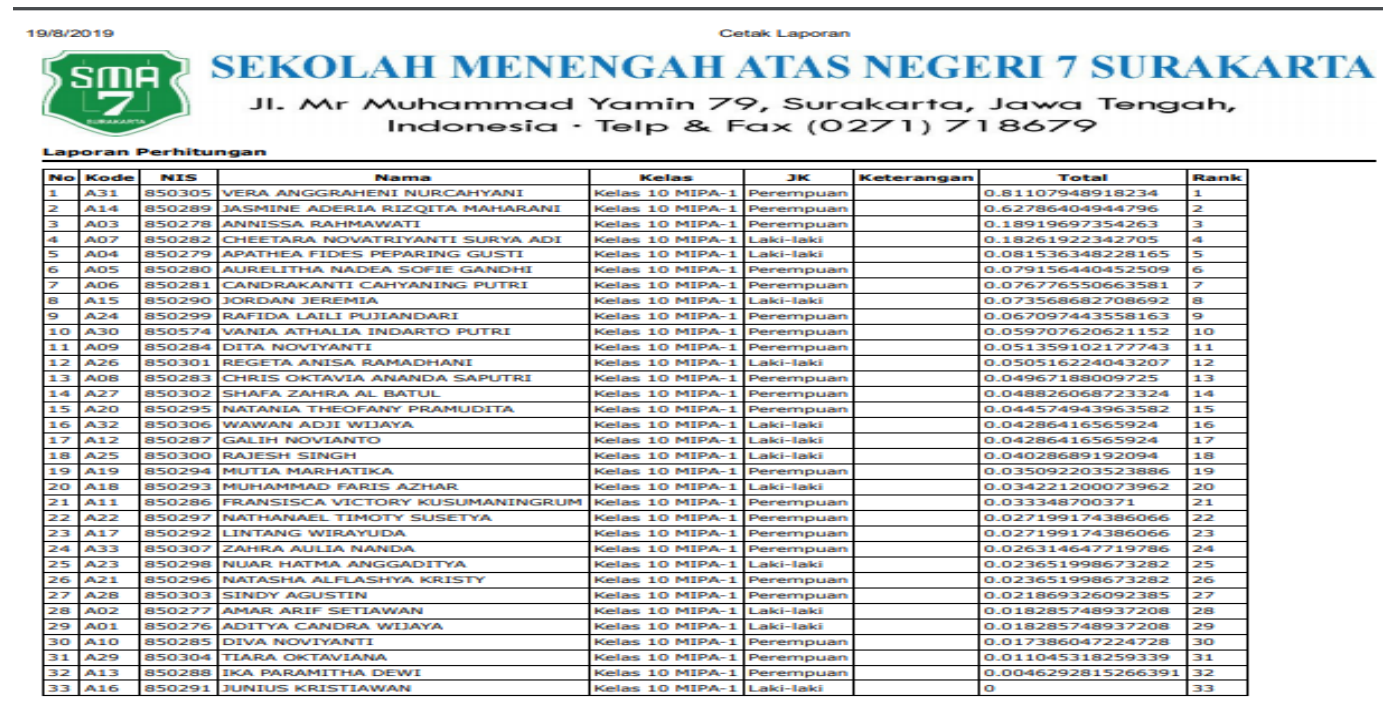

\subsection{Pengujian Fungsional}

Gambar 6. Halaman Laporan Hasil perhitungan Seleksi

Pengujian sistem menggunakan pengujian Black box dimana tujuan dari pengujian ini yaitu untuk mengetahui fungsi-fungsi khusus dari aplikasi yang dikembangkan. Seperti pada tabel 11 kesimpulan hasil ujian:

Tabel 11. Kesimpulan Hasil Pengujian

\begin{tabular}{|c|c|c|c|}
\hline No & Skenario pengujiuan & Item Pengujian & Hasil \\
\hline 1. & Verivikasi Login & Menu Login & Valid \\
\hline \multirow{3}{*}{2.} & \multirow{3}{*}{ Simpan Data } & Form user & Valid \\
\hline & & Form Data Debitur & Valid \\
\hline & & Form ubah password & Valid \\
\hline \multirow{3}{*}{3.} & \multirow{3}{*}{ Cari Data } & Form user & Valid \\
\hline & & Form Kriteria & Valid \\
\hline & & Form Data Debitur & Valid \\
\hline \multirow{3}{*}{4.} & \multirow{3}{*}{ Edit Data } & Form user & Valid \\
\hline & & Form Kriteria & Valid \\
\hline & & Form Data Debitur & Valid \\
\hline \multirow{3}{*}{5.} & \multirow{3}{*}{ Hapus Data } & Form user & Valid \\
\hline & & Form Kriteria & Valid \\
\hline & & Form Data Debitur & Valid \\
\hline 6. & Perhitungan & Form Perhitungan & Valid \\
\hline
\end{tabular}

Hasil pengujian tersebut, menunjukkan bahwa perangkat lunak yang digunakan secara fungsional memberikan hasil yang sesuai dengan apa yang diharapkan, semua fungsi pada aplikasi dapat berjalan dengan baik

\section{KESIMPULAN DAN SARAN}

5.1 Kesimpulan

1) Telah berhasil membuat aplikasi Sistem Pendukung Keputusan dengan menggunakan Metode AHP (Analytical Hyrarchy Proses) dan TOPSIS (Technique For Order Of Preference By Similarity To Ideal Solution) untuk seleksi pemilihan siswa berprestasi. 
2) Pengujian dalam sistem pendukung keputusan ini menggunakan metode Blackbox, dimana Aplikasi yang dibangun secara fungsional dapat berjalan dengan baik.

3) Hasil uji validitas menunjukan bahwa kinerja sistem sudah baik, dukungan menjadikan sistem baru sebesar $84,85 \%$, dengan menggunakan 5 kriteria yaitu nilai sikap, nilai kognitif, prestasi, keterlambatan dan kehadiran, dengan menggunakan 5 kriteria membuat penilaian siswa berprestasi lebih obyektif, maka dengan berdasarkan uji validitas tersebut dapat dinyatakan bahwa sistem yang dibuat layak digunakan untuk menentukan siswa berprestasi di SMA N 7 Surakarta.

\subsection{Saran}

1) Metode AHP (Analytical Hyrarchy Proses) dan TOPSIS (Technique For Order Of Preference By Similarity To Ideal Solution) ini dapat di terapkan secara pararel dengan sistem lama, agar sistem nantinya memiliki kesesuaian dengan proses penentuan pemilihan siswa berprestasi di SMA N 7 Surakarta.

2) Penelitian ini menggunakan 5 kriteria, yaitu Nilai Sikap, Nilai Kognitif, Prestasi, Keterlambatan dan Kehadiran, sehingga untuk menunjang pengembangan sistem yang lebih baik lagi untuk ditambahkan beberapa kriteria penentu lainnya yang dapat memperkuat dalam pengambilan keputusan penentuan siswa berprestasi.

3) Perlu adanya interegasi database nilai siswa sekolah dengan database aplikasi untuk mempermudah proses input data nilai siswa.

\section{DAFTAR PUSTAKA}

Chamid, A. A., \& Murti, A. C. (2018). Prioritization of Natural Dye Selection In Batik Tulis Using AHP and TOPSIS Approach. IJCCS (Indonesian Journal of Computing and Cybernetics Systems), 12(2), 129. https://doi.org/10.22146/ijccs.29813

Heru Lumaksono, H. (2017). Sistem Pendukung Keputusan untuk Menentukan Alat Tangkap yang Sesuai bagi Nelayan di Madura. Seminar MASTER 2017 PPNS, 1509, $1-6$.

Juliyanti, Mohammad Isa Irawan, dan I. M. (2011). Pemilihan Guru Berprestasi Menggunakan Metode Ahp Dan Topsis. Prosiding Seminar Nasional Penelitian Pandidikan Dan Penerapan MIPA Fakultas MIPA Universitas Negeri Yogyakarta, 63-68.

Kusrini, \& Gole, A. W. (2007). Sistem Pendukung Keputusan Penentuan Prestasi Pegawai. Seminar Nasional Aplikasi Teknologi Informasi, 2007(Snati).

Kusumadewi, S. (2005). Pencarian bobot atribut pada Multiple Attribute Decision Making (MADM) dengan Pendekatan Obyektif Menggunakan Algoritma Genetika. GEMATIKA JURNAL MANAJEMEN INFORMATIKA, 7(1), 97-105.

Purwitasari, K. D., \& Pribadi, F. S. (2015). Implementasi Sistem Pendukung Keputusan Peminatan Peserta Didik SMA menggunakan Metode AHP ( Analytic Hierarchy Process ) dan SAW ( Simple Additive Weighting ). Jurnal Teknik Elektro, 7(2).

Saaty, T. L. (2008). Decision making with the Analytic Hierarchy Process. Scientia Iranica, 9(3), 215-229. https://doi.org/10.1504/ijssci.2008.017590

Sejati Purnomo, E. N., Widya Sihwi, S., \& Anggrainingsih, R. (2013). Analisis Perbandingan Menggunakan Metode AHP, TOPSIS, dan AHP-TOPSIS dalam Studi Kasus Sistem Pendukung Keputusan Penerimaan Siswa Program Akselerasi. Jurnal Teknologi \& Informasi ITSmart, 2(1), 16. https://doi.org/10.20961/its.v2i1.612 